\title{
Pathomorphological Studies of Peste Des Petits Ruminants (PPR) in Goats of Navsari and Valsad Districts, India
}

\author{
Yash R. Patel $^{1 *}$, Jignesh M. Patel ${ }^{1}$, Priti D. Vihol ${ }^{1}$, I.H. Kalyani , \\ Jayesh B. Solanki ${ }^{3}$ and Pratik P. Panchal ${ }^{1}$
}

${ }^{1}$ Department of Veterinary Pathology, Vanbandhu College of Veterinary Sciences and Animal

Husbandry, Navsari Agricultural University, Navsari-396 450, Gujarat, India

${ }^{2}$ Department of Veterinary Microbiology, Vanbandhu College of Veterinary Sciences and

Animal Husbandry, Navsari Agricultural University, Navsari-396 450, Gujarat, India

${ }^{3}$ Department of Veterinary Parasitology, Vanbandhu College of Veterinary Sciences and Animal

Husbandry, Navsari Agricultural University, Navsari-396 450, Gujarat, India

*Corresponding author

\section{A B S T R A C T}

\begin{tabular}{|l|}
\hline Ke y w or d s \\
C- ELISA, \\
Goat, PPR, \\
Pathomorphology. \\
\hline Article Info \\
\hline Accepted: \\
04 October 2017 \\
Available Online: \\
10 December 2017 \\
\hline
\end{tabular}

During the seroprevalence study of PPR a total 210 serum samples were collected from goats of Navsari and Valsad districts of South Gujarat. Out of them 99 samples were found positive for PPRV antibody by C- ELISA kit and these PPR positive goats put under continuous observations. Out of these 99 PPR positive goats, 15 goats were died which were consider as a suspected death due to PPR disease. Post mortem was performed in death animals and gross lesions were noted as well as tissue samples were collected in $10 \%$ neutral buffer formalin for histological study. Tissue samples were processed, slide were prepared and subjected to histological examination. Characteristics microscopic lesions like syncytial cell formation, infiltration of mononuclear cells and necrosis were observed in lung, intestine, spleen, kidney and liver tissue.

\section{Introduction}

Peste des petits ruminants (PPR) is an acute febrile viral disease of goat and sheep caused by RNA virus belonging to the genus Morbillivirus of Paramyxoviridae family (Gibbs et al., 1979). PPR is also known as kata, stomatitis- pneumoentritis complex, goat plaque and pseudo - rinderpest (Jubb et al., 2007). The disease is highly contagious causing varying degree of morbidity and mortality in susceptible animals (Radostits et al., 2007).
PPR virus is normally transmitted by aerosal route, but may also spread through direct contact by means of contaminated water/feed. Substantial quantities of virus are found in ocular, nasal or oral secretions in early stage of sick goats and in the faeces in late stage of disease (Abegunde and Abu, 1977). PPRV was serologically confirmed from Gujarat by Hinshu et al., (2001) followed by many researchers (Tiwari, 2004, Kanani et al., 2006, Nagraj, 2006, Balamurugan et al., 2011 
and Chandrahas et al., 2011). Recently, an outbreak of PPR was reported in Navsari and Valsad district of Gujarat (Sharma et al., 2015 and Thakor et al., 2016). Hence the present study was decided for pathomorphological study as well as use of latest techniques for diagnosis and detection of PPR antigen in-situ condition.

\section{Materials and Methods}

For pathomorphological study only those animals were taken into consideration which represented PPR infection in flock according to C- ELISA result. Out of 210 serum samples 99 samples were shown positivity for PPR antibody in C- ELISA. Out of these 99 PPR infected animals, 15 animals were dead and these dead animals were subjected to Post mortem examination. During postmortem examination gross pathological lesions were recorded if any. After recording the gross lesions the tissues from various organs (e.g. lung, liver, intenstine, spleen, kidney, heart and trachea) were collected and subsequently preserved in $10 \%$ neutral buffered formalin for histopathological examination.

Following fixation, tissue samples were processed for histopathology by paraffin embedding technique as per standard protocol (Luna, 1968). The blocks of tissue were cut in to section of four to six microns thickness, the sections were stained by Harri's Haematoxylin and Eosin staining method (Culling, 1969).

\section{Results and Discussion}

Gross examination of respiratory tract revealed frothy exudates and haemorrhages in tracheal mucosa (Figure 1). Varying degree of congestion, haemorrhages, red hepatization, emphysema and consolidation was observed in right lobe of lung (Figure 2) along with firm consistency. Whereas in intestine, hemorrhagic strips were found on mucosal surface of caecum (Figure 3) with raised nodules. Spleen revealed characteristics lesions of splenomegaly and edematous. Additionally, liver revealed haemorrhages on the surface, presence of serosengunious fluid was also noticed in pericardial sac of heart (Figure 4) and minor haemorrhages on cortico- medullary junction of kidney.

The morbid pathomorphological lesions in lungs, trachea, caecum, spleen, liver, heart and kidneys observed in this study were partly in agreement with previous report made by El-Yuguda et al., (2009), Al-Naeem et al., (2009), Zahur et al., (2009), Abd El-Rahim et al., (2010), Chauhan et al., (2011), Jagtap et al., (2012), Rosemary et al., (2013), Patel et al., (2015) and Ekambaram et al., (2015) in sheep and goat. The pneumonic lungs and hemorrhagic trachea probably due to descending upper respiratory infection of PPR complicated by secondary bacterial infection (Rosemary et al., 2013). Moreover, congestion and red hepatization of lung were probably suggestive of PPRV involvement (Kumar et al., 2004).

Most prominent histological changes were observed in lung, intestine, kidney, liver, spleen, lymph node and heart. Histopathological examination of lungs revealed alveolar dilatation, emphysema, thickening of alveolar septa, infiltration of mononuclear cells (Figure 5), eosinophilic intracytoplasmic inclusion body and interstitial pneumonia along with pink colour serous exudates. Presence of exudate in bronchioles, necrosis and shedding of bronchial epithelium (Figure 6) was also noted in present study. In trachea, degeneration and cystic lesions in tracheal gland (Figure 7) and infiltration of mononuclear inflammatory cells in tracheal sub-mucosa were observed. In intestine, necrosis of epithelium/crypts, haemorrhages 
and infiltration of mononuclear cells into submucosa with sever loss of intestinal villi were common findings (Figure 8 and 9). Spleen and lymph node revealed haemorrhages and depletion of lymphoid cell in cortex and medullary cords. Liver shows lesions of degeneration, sinusoidal congestion and infiltration of mononuclear cells in the sinusoidal space along with syncytial cell.
Whereas in kidney, degenerative changes accompanied by desquamation of epithelium lining of tubules, haemorrhages, mild glomerular atrophy and interstitial nephritis (Figure 10). While mild pathological changes were observed in heart like congestion, haemorrhages, degenerative changes, infiltration of mononuclear cells and focal area of necrosis.

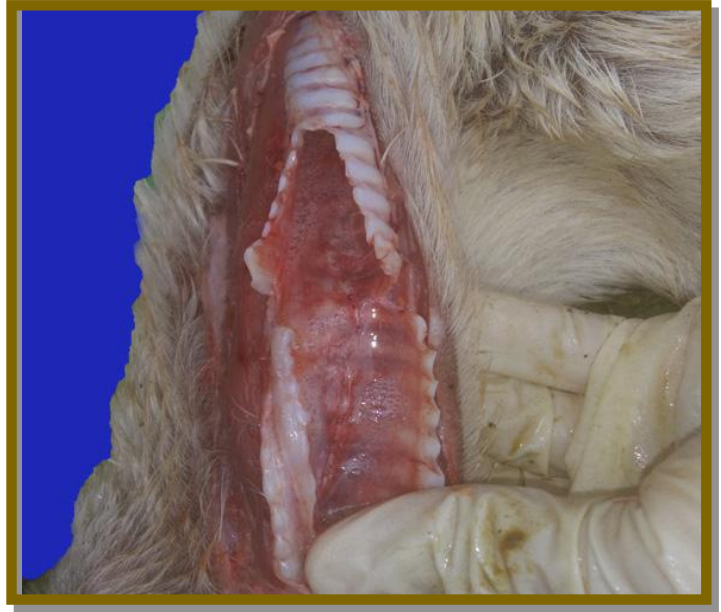

Fig.1 Frothy exudates and hemorrhages in trachea

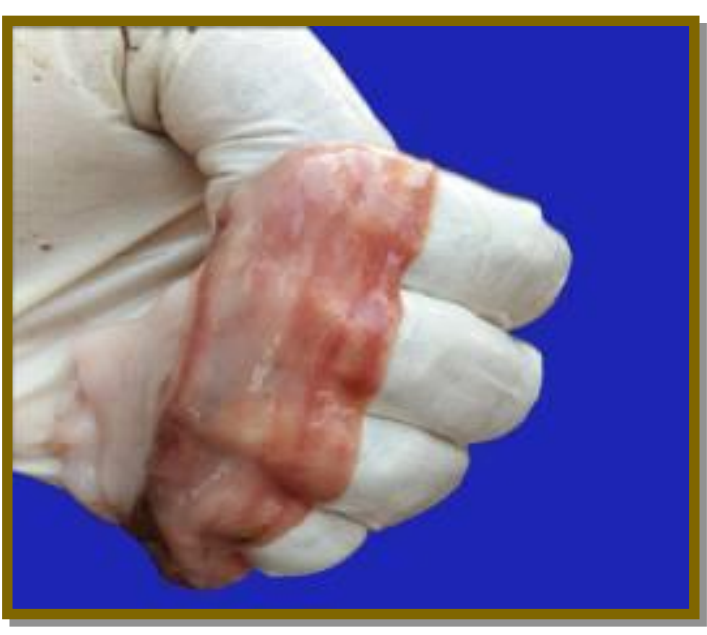

Fig.3 Hemorrhagic strips in mucosal surface of caecum

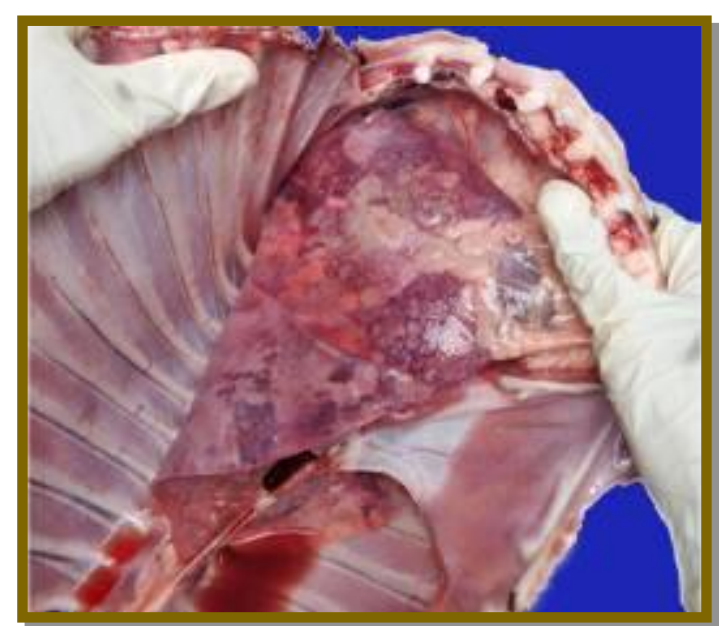

Fig.2 Congestion, hemorrhages, red hepatization and consolidation in right lobe of lung

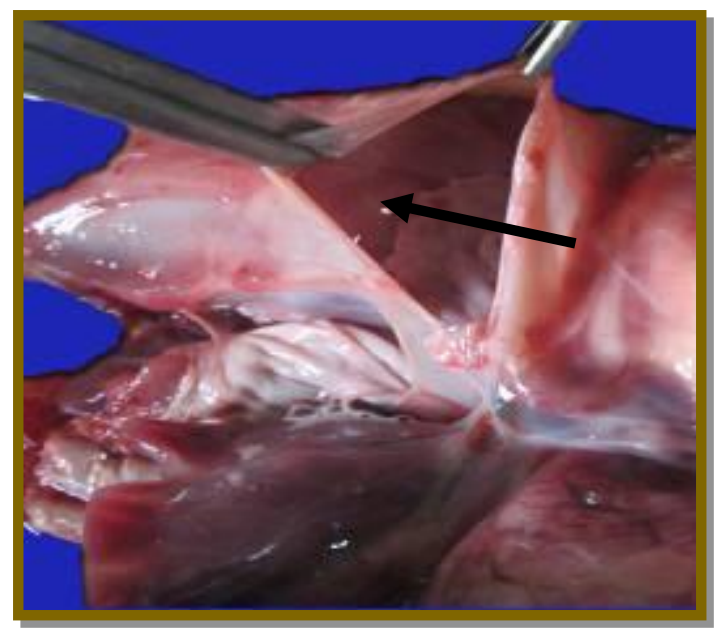

Fig.4 Presence of serosengunious fluid (arrow) in pericardial sac of heart 


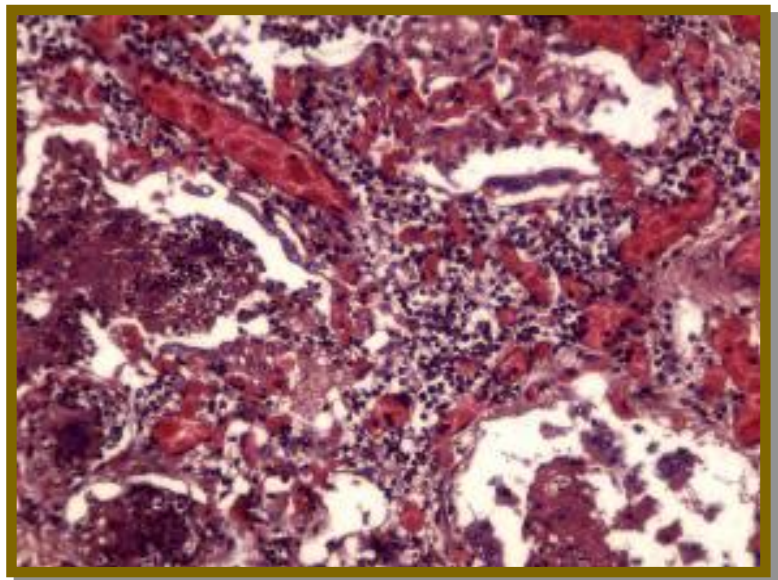

Fig.5 Lung, infiltration of mononuclear inflammatory cells in inter alveolar septa and alveoli lumen along with alveoli capillary congestion ( $\mathrm{H}$ and $\mathrm{E} \times \mathrm{2} 2)$

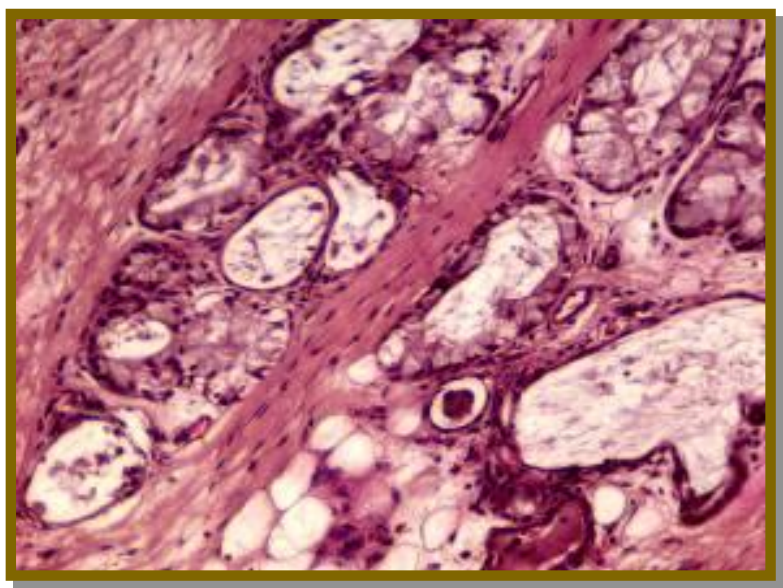

Fig.7 Trachea, degeneration and cystic lesions in tracheal gland ( $\mathrm{H}$ and $\mathrm{E} \times \mathrm{x} 20)$

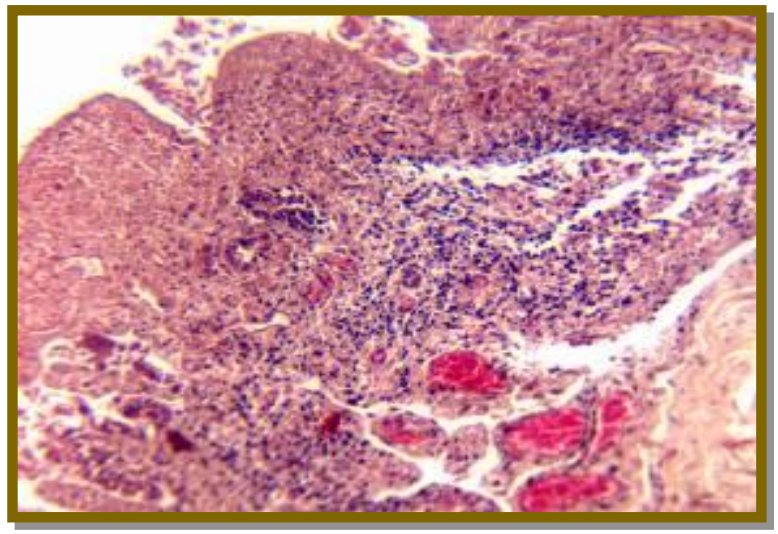

Fig.9 Intestine, infiltration of mononuclear inflammatory cells in submucosa of intestine (H and E x 20)

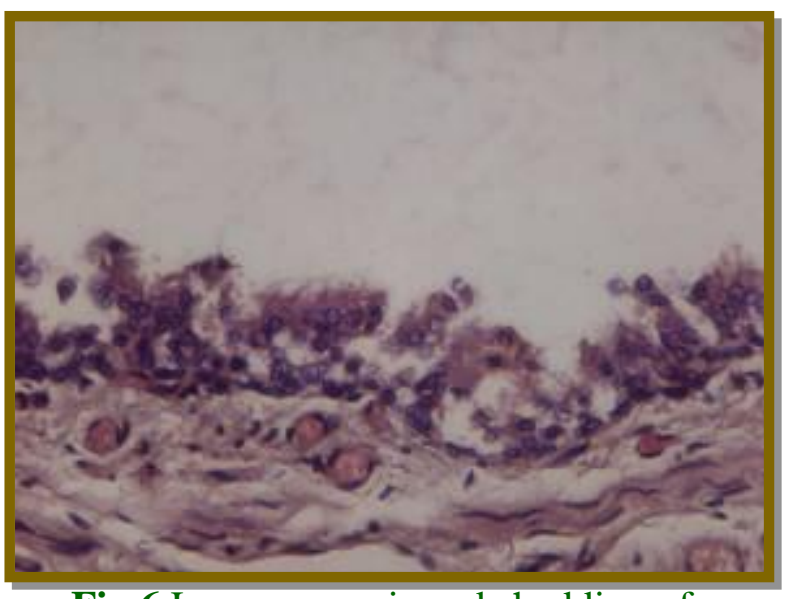

Fig.6 Lung, necrosis and shedding of bronchial epithelium (H and E x 20)

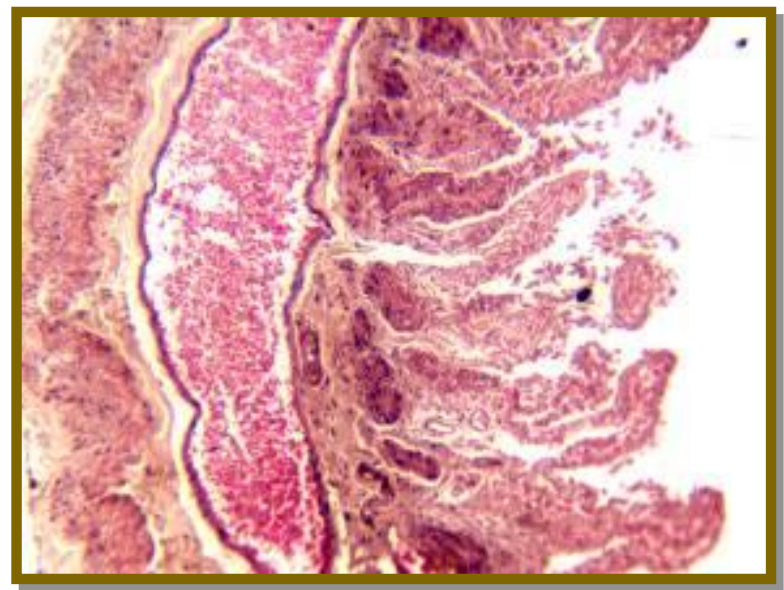

Fig.8 Intestine, hemorrhages in submucosa, blunting, necrosis and sloughing of intestine villi ( $\mathrm{H}$ and $\mathrm{E} x \mathrm{20}$ )

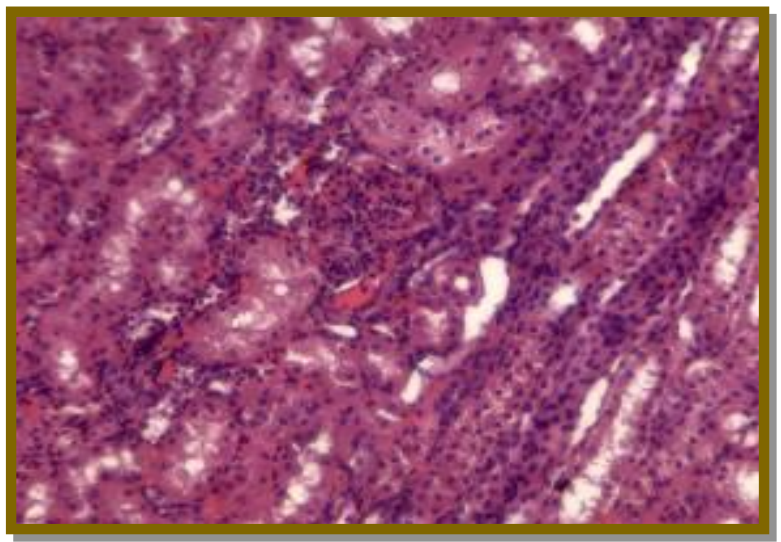

Fig.10 Kidney, infiltration of mononuclear inflammatory cells in interstitial space ( $\mathrm{H}$ and $\mathrm{E} \times 20)$ 
Histopathological examination of lungs revealed alveolar dilatation, emphysema and infiltration of mononuclear cells along with pink colour serous exudate which was shown similarity with the earlier observations of various researchers (Aktas et al., 2011; Jagtap et al., 2012; Patel et al., 2015 and Maina et al., 2015). Presence of syncytial cells and eosinophilic intracytoplasmic inclusion body in bronchial epithelium cells was supported by the earlier reports of Brown et al., (1991), Islam et al., (2001), Kumar et al., (2004), Toplu (2004), Kul et al., (2007) and Saglam and Temur (2009). Though interstitial pneumonia was evident and partially agreement with the findings of Kumar et al., (2004) and Kul et al., (2007). Presence of exudate in bronchi and hyperplasia of brochial epithelium was noted in present study which was also same as the findings of Aktas et al., (2011) and Maina et al., (2015).

Necrosis of epithelium/crypts in intestine was also found by Kumar et al., (2004), Aktas et al., (2011) and Patel et al., (2015). Whereas haemorrhages and infiltration of mononuclear cells into submucosa were partially agreement with the report of Maina et al., (2015).

Loss of intestinal villi might be due to the epitheliotropic nature of PPR virus (Maina et al., 2015) may lead to necrosis of epithelium cells of villi.

According to present and earlier reports of Islam et al., (2001), Kul et al., (2007), Maina et al., (2015) and Patel et al., (2015) lymphoid cell depletion was observed in cortex and medullary cords of spleen and lymph node. It might be due to the sever lymphocytolysis in lymphoid tissues by PPR virus (Kul et al., 2007). In agreement with the present findings Aktas et al., (2011) and Madboli and Ali (2012) also reported degeneration and infiltration of mononuclear cells in the sinusoidal space in liver.
Histopathological lesions of kidney included degenerative changes, desquamation of epithelium lining of tubules, interstitial nephritis and mild glomerular atrophy were partly in accordance with the observations of Jagtap et al., (2012) and Patel et al., (2015). Further, in present study histopathological changes of heart included congestion, haemorrhages, degenerative changes and focal area of necrosis were supported by the observation of Jagtap et al., (2012). Although the type of lesions was more or less similar in all the animals, there was variations in the severity and involvement of the organs.

\section{Acknowledgements}

The authors are highly thankful to the Dean and Principal for providing facilities and fund. Authors also wish to thank Dr. I. H. Kalyani, Associate Professor and Head, Department of Veterinary Microbiology and Dr. J. M. Patel, Assistant Professor, Department of Veterinary Pathology, Vanbandhu College of Veterinary science and Animal Husbandry, Navsari Agricultural University, Navsari, Gujarat, India for extra support and their guidance in screening tissue samples.

\section{References}

Abd El-Rahim, I. H. A., Sharawi, S. S. A., Barakat, M. R. and Nahas, E. M. 2010. An outbreak of peste des petits ruminants in migratory flocks of sheep and goats in Egypt in 2006. Revue Scientifique et Technique De L Office International Des Epizooties, 29(3): 655-662.

Abegunde, A. A. and Adu, F. 1977. Excretion of the Virus of Peste des Petits Ruminants by goats. Bulletin of Animal Health and Production in Africa, 25: 307-311.

Aktas, M. S., Ozkanlar, Y., Simsek, N., Temur, A. and Kalkan, Y. 2011. Peste des petits ruminants in suckling lambs case report. Israel Journal of Veterinary Medicine, 66 (1): 39- 44. 
Al-Naeem, A., Abu-Elzein, E., Abdelsalam, E., Al-Hizab1, F., Housawil, F. and ALAfaleq, A. 2009. Clinico-pathological Response of indigenous sheep and goats to a virulent gazelle Peste des petits ruminants virus (PPRV). Scientific Journal of King Faisal University, 10: 1420-1430.

Balamurugan, V., Saravanan, P., Sen, A., Rajak, K. K., Bhanuprakash, V., Krishnamoorthy, P. and Singh, R. K. 2011. Sero- pidemiological study of peste des petits ruminants in sheep and goats in India between 2003 and 2009. Rev. Sci. tech. Off. int. Epiz., 30(3): 889-896.

Brown, C. C., Mariner, J. C. and Olander, H. J. 1991. An Immunohistochemical Study of the Pneumonia Caused by Peste des Petits Ruminants Virus. Veterinary Pathology, 28: 166-170.

Chandrahas, S., Chandel, B. S., Chauhan, H. C. and Dadawala, A. I. 2011. Seroprevalence of PPR in sheep and goats of North Gujarat. Indian Journal of Small Ruminants, 17(1): 118-121.

Chauhan, H. C., Lambade, P. S., Sen, A., Dadawala, A. I., Ranaware, P. B., Chandel, B., Jhoshi, D. V., Patel, S. S., Kumar, P., Shah, N. M. and Kher, H. N. 2011. The use of pathological and histopathological techniques in the diagnosis of peste des petits ruminatnts in India. Veterinarian Italiana, 47 (1): 4147.

Culling, C. F. A. 1969. Handbook of histopathological and histochemical techniques. $3^{\text {rd }}$ edn., butterworth and company, Durban.

Ekambaram, B., Rajesh, M. M. and Kumar, C. V. 2015. Diagnosis and Management of Peste Des Petits Ruminants (PPR) in Ovines. Intas Polivet, 16(2): 418-421.

El-Yuguda, A. D., Abubakar, M. B., Nabi, A. B., Andrew, A. and Baba, S. S. 2009. Outbreak of Peste Des Petits Ruminant in an Unvaccinated Sahel Goat Farm in Maiduguri, Nigeria. African Journal of Biomedical Research, 12(1), 83-87.

Gibbs, E. P., Taylor, W. P., Lawman, M. J. P. and Bryant, J. 1979. Classification of peste des petits ruminants virus as the fourth member of the genus morbillivirus. Intervirology, 11(5): 268-274.

Hinshu, V., Kher, N., Jhala, S. and Chandel, M.K. 2001. Seroprevalence of Peste des petits ruminants (PPR) in Gujarat. Indian J. Comp. Microbiol. Immunol. Infect. Dis., 22 (1): 81.

Islam, M. R., Shamsuddin, M., Das, P. M. and Dewan, M. L. 2001. An outbreak of Peste des petits ruminants in Black Bengal goats in Mymensingh, Bangladesh. Bangladesh Journal of Veterinary Medicine, 18: 14-19.

Jagtap, S. P., Rajak, K. K., Garg, U. K., Sen, A., Bhanuprakash, V., Sudhakar, S. B., Balamurugan, V., Patel, A., Ahuja, A., Singh, R. K. and Vanamayya, P. R. 2012. Effect of immunosuppression on pathogenesis of peste des petits ruminants (PPR) virus infection in goats. Microbial Pathogenesis, 52: 217- 226.

Jubb, Kennedy and Palmer. 2007. Pathology of Domestic Animal, $5^{\text {th }}$ edn., China Elsevier Ltd., Pp 150- 151.

Kanani, A., Sutariya, P., Shukla, R. and Shukla, R. 2006. Seroprevalence of Peste des petits ruminants (PPR) in small ruminants of Gujarat State. Indian J. Field. Vet., 1(4): 22- 23

Kul, O., Kabakci, N., Atmaca, H. T. and Ozkul, A. 2007. Natural Peste des petits ruminants virus infection: novel pathologic findings resembling other morbillivirus infections. Veterinary Pathology, 44: 479-486.

Kumar, F. P., Tripathi, B. N., Sharma1, A. K., Kumar, R., Sreenivasa, B. P., Singh, R. P., Dhar, P. and Bandyopadhyay, S. K. 2004. Pathological and Immuno histochemical Study of Experimental Peste Des Petits Ruminants Virus Infection in Goats. Journal of veterinary medicine B., 51: 153-159.

Luna, A. G. 1968. Manual of histological staining methods of the Armed Forced Institute of Pathology, $3^{\text {rd }}$ edn., Mc Graw Hill Book Co, London, Pp. 124-125. 
Madboli, A. A. and Ali, S. M. 2012. Histopathological and Immuno histochemical Studies on the Female Genital System and Some Visceral Organs in Sheep and Goat Naturally Infected by Peste Des Petits Ruminants Virus. Global Veterinaria, 9(6): 752-760.

Maina, S. M., Gitao, C. G. and Gathumbi, P. K. 2015. Clinico-Pathological Observations in Sheep and Goats Exposed to Lineage I Peste Des Petits Ruminants Virus Infection In Kenya. Journal of Experimental Biology and Agricultural Sciences, 3(1): 72- 80.

Nagraj, 2006. Assessment of different gene target for detection of Peste des petits ruminants by RT-PCR and Sequence analysis of $\mathrm{F}$ and $\mathrm{N}$ gene segments. M.V.Sc. thesis, AAU, Anand, Gujarat.

Patel, J. M., Patel, D. R., Mavadiya, S. V., Solanki, J. B., Vihol, P. D., Sharma, K. K., Trangadia, B. J. and Kalyani, I. H. 2015. Clinicopathological investigation of an outbreak of peste des petits ruminants in small ruminants in South Gujarat, India. Indian Journal of Veterinary Pathology, 39(1): 20- 23.

Radostits, O. M., Blood, D. C. and Gray, C. C. 2007. Veterinary Medicine: A text book of the diseases of cattle, horse, sheep, pigs and goats. London: Elsevier, 10: 1242-1243.

Rosemary, I., Nwoha, O., Omamegbe, J. O. and Nwakundu, N. O. 2013. Clinicopathological findings in West African dwarf goats with peste des petits ruminants infection. Philippine Journal of Veterinary and Animal Sciences, 39 (1): 125-132.
Saglam, Y. S. and Temur, A. 2009. Immunohistochemical Detection of Peste des Petits Ruminants (PPR) Viral Antigen from the Cases of Naturally Occurring Pneumonia in Sheep. Kafkas Univ Vet Fak Derg, 15(3): 423-428.

Sharma, K. K., Kshirsagar, D., Kalyani, I., Patel, D., Vihol, P. and Patel, J. 2015. Diagnosis of peste des petits ruminants infection in small ruminants through inhouse developed Indirect ELISA: Practical considerations. Veterinary World, 8(4): 443- 448.

Thakor, R. B., Patel, M. D., Patel, R. M. and Kalyani, I. H. 2016. Seroprevalence of peste des petits ruminants in goats of South Gujarat. Indian Journal of Small Ruminants, 22(2): 252-254.

Tiwari, A. 2004. Prevalence of Peste des Petits ruminants (PPR) virus in small ruminants of Gujarat and its characterization by RTPCR/ RFLP and SSCP profiles. M.V.Sc. thesis, AAU, Anand, Gujarat.

Toplu, N. 2004. Characteristic and Noncharacteristic Pathological Findings in Peste des Petits Ruminants (PPR) of Sheep in the Ege District of Turkey. Journal of Comparative Pathology, 131: 135-141.

Zahur, A. B., Irshad, H., Hussain, M., Ullah, A., Jahangir, M., Khan, M. Q. and Farooq, M. S. 2009. The epidemiology of peste des petits ruminants in Pakistan. Revue Scientifique et Technique De L Office International Des Epizooties, 27(3): 877884.

\section{How to cite this article:}

Yash R. Patel, Jignesh M. Patel, Priti D. Vihol, I.H. Kalyani, Jayesh B. Solanki and Pratik P. Panchal. 2017. Pathomorphological Studies of Peste Des Petits Ruminants (PPR) in Goats of Navsari and Valsad Districts. Int.J.Curr.Microbiol.App.Sci. 6(12): 238-244. doi: https://doi.org/10.20546/ijcmas.2017.612.029 